\title{
Plant and Soil Water Potentials Following Fire in a Northern Mixed Grassland
}

\section{R.E. REDMANN}

Highlight: Leaf water potential, osmotic potential, and soil moisture were measured in mixed grassland during the growing season following an October fire. Plant and soil water stress increased near the end of the May-August period in both burned and control sites. Potentials in nothern wheatgrass and junegrass become lower in burned than in control plots as the growing season progressed. Increased plant water stress was judged sufficient to account for the reductions in productivity which have been observed after fire.

The extensive literature describing the effects of fire on grassland composition and productivity has been reviewed by Daubenmire (1968) and Vogl (1974). Some studies (e.g., McMurphy and Anderson 1963) have compared soil moisture content of burned and unburned plots; however, no information on plant water status has been found in the literature.

Fire is used as a management tool in many grasslands; accidental and naturally caused fires also are important. Rowe (1969) carried out a survey which suggested that lightningcaused fires are relatively common in the grasslands of southwestern Saskatchewan. He estimated that one year in six has the combination of abundant grass fuel and weather conditions conducive to widespread fires in the region.

In 1969, lightning-caused fires burned parts of the Matador Field Station, site of an intensive ecosystem study under the Canadian International Biological Programme. An accidental fire in October, 1970, which burned several hectares of the Station, provided an opportunity to study the effect of burning on plant-soil water relationships. The objectives were to measure seasonal changes in the water status of two dominant grasses growing on the burned and unburned plots, and to relate plant water status to environmental conditions and plant productivity.

\section{Experimental Area}

The Matador Field Station is located $45 \mathrm{~km}$ north of Swift Current, Sask., Canada. The vegetation of the site is described as the Agropyron-Koeleria faciation of the mixed prairie assocation (Coupland et al. 1973). Dominant plant species include northern wheatgrass (Agropyron dasystachyum) and june (Koeleria cristata), which contribute $44 \%$ and $6.5 \%$ of the total plant biomass, respectively. At midgrowing season approximately three-fourths of the above-ground biomass consists of dead shoot material. The total amount of standing dead in this ungrazed sward can exceed $500 \mathrm{~g} \mathrm{~m}^{-2}$. A detailed

\footnotetext{
The author is associate professor, Department of Plant Ecology, University of Saskatchewan, Saskatoon, Canada S7N OWO.

This research was supported by the National Research Council of Canada and carried out as part of the International Biological Programme. The technical assistance of $E$. Huang is gratefully acknowledged.

Manuscript received December 12, 1977.
}

discussion of sward structure appears in Coupland et al. (1973).

The climate of the region is classified as Type VII 5 (VI) Arid, with Cold Season (Walter and Leith 1960). Annual precipitation averages $388 \mathrm{~mm}$, approximately one-fourth of which comes as snowfall. One-third of the annual precipitation falls during June and July; late summer drought is typical. Mean air temperatures range from $19^{\circ} \mathrm{C}$ (July) to $-13^{\circ} \mathrm{C}$ (January) with an annual mean of $3.3^{\circ} \mathrm{C}$. Ripley (1973) discusses the climate of the Matador region.

The soils of the Station belong to the Sceptre Association, consisting mainly of chernozemic brown soils of heavy clay texture, developed on glaciolacustrine deposits (deJong and Stewart 1973). The topography is that of a very gently undulating plain, which is locally dissected by ravines.

An accidental fire in October, 1970, burned a strip, several hundred meters in width, across a homogeneous section of the Field Station before being extinguished. Sampling was done along the burned and unburned sides of the fire line.

\section{Methods}

Water potentials and osmotic potentials of northern wheatgrass and junegrass were determined at $14 \mathrm{~h}$ on 18-21 days between May 18 and August 19,1971 . The youngest fully emerged leaf blades were removed from shoots in the field and sealed in $5-\mathrm{cm}^{3}$ polypropylene chambers. Four replicates, each consisting of 3-4 blades were collected at each sampling time. Water potential of the leaf tissue in the chambers was measured using Spanner-type thermocouple psychrometers. At each sampling time ten additional leaf blades were placed in each of four $3-\mathrm{cm}^{3}$ plastic syringes for determination of osmotic potential. Freezing-point depression of sap expressed from the leaf tissue after freezing and thawing was determined using a Knauer cyroscopic osometer. Details of the psychrometer and freezing-point equipment and measurement procedures are described by Redmann (1976).

Soil moisture content in the $0-15 \mathrm{~cm}$ layer was determined gravimetrically. Soil matric potential was calculated from the gravimetric measurements using a desorption curve determination by de Jong and Stewart (1973) for the Matador soil type.

\section{Results and Discussion}

Water Status in Burned and Unburned Plots

Water potentials of northern wheatgrass and junegrass growing in both the control and burnd plots were about -15 and -20 bars during late May (Fig. 1). Values rose to around -10 bars during June and early July, after which a strong downward trend in water potential was observed. The lowest water potentials in northern wheatgrass and junegrass were -35 and -45 bars, respectively. Junegrass probably exhibited greater stress because its root system tends to be confined to the shallower soil layers (Coupland and Johnson 1965), which dry out earlier. 


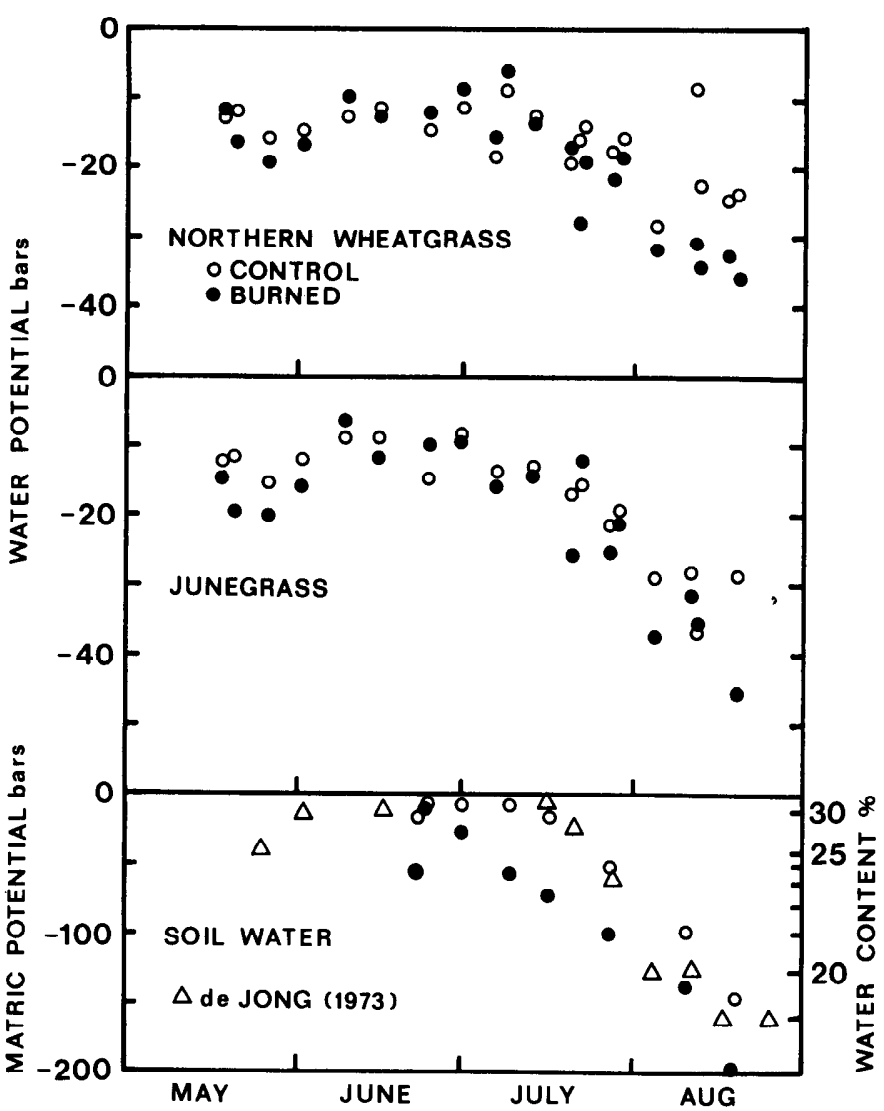

Fig. 1. Seasonal patterns of plant water status in northern wheatgrass and junegrass and soil moisture $(0-15 \mathrm{~cm})$ in burned and unburned sites. Plots were burned the previous October. Each point is the mean of four replications; standard deviations for northern wheatgrass averaged 1.3 bars; for junegrass, 1.7 bars. Soil moisture measured in nearby unburned plots by de Jong (1973) is also shown.
Water potentials and osmotic potentials of both species were significantly lower on burned than on control plots late in the growing season when potentials were lowest (Fig. 2). For example, when plant water potential of northern wheatgrass on the control plot was -25 bars, water potential in the burned area was significantly lower ( -32.4 bars). When water and osmotic potentials of control plants were -15 bars, potentials on the burned site were not significantly lower $(0.05$ probability level, tested using procedures from Steel and Torrie 1960). Osmotic potentials of junegrass from burned plots were also significantly lower late in the growing season; water potentials were not significantly lower, even late in the season, because of the large variation at that time.

Regression lines of osmotic potentials and water potentials within the species were not significantly different $(0.05$ level). Water potential (WP) equalled osmotic potentials (OP) and since

$$
\mathrm{WP}=\mathrm{OP}+\mathrm{TP},
$$

turgor pressure (TP) was nil. Redmann (1976) found that turgor effects in northern wheatgrass were only important at water potentials above about -15 bars.

\section{Causal Factors in Increased Stress on Burned Plots}

Decreasing water potential over the season was related to soil moisture and precipitation patterns. Precipitation during August, 1971, was only $8 \%$ of the long-term average. Rainfall during the May-July period was about $88 \%$ of the 30 -year mean. August was also hot: mean maximum air temperature was $5.6^{\circ}$ above average.

Soil moisture content on the control plots dropped from about $35 \%$ in early July to $19 \%$ near the end of August (Fig. 1). Data

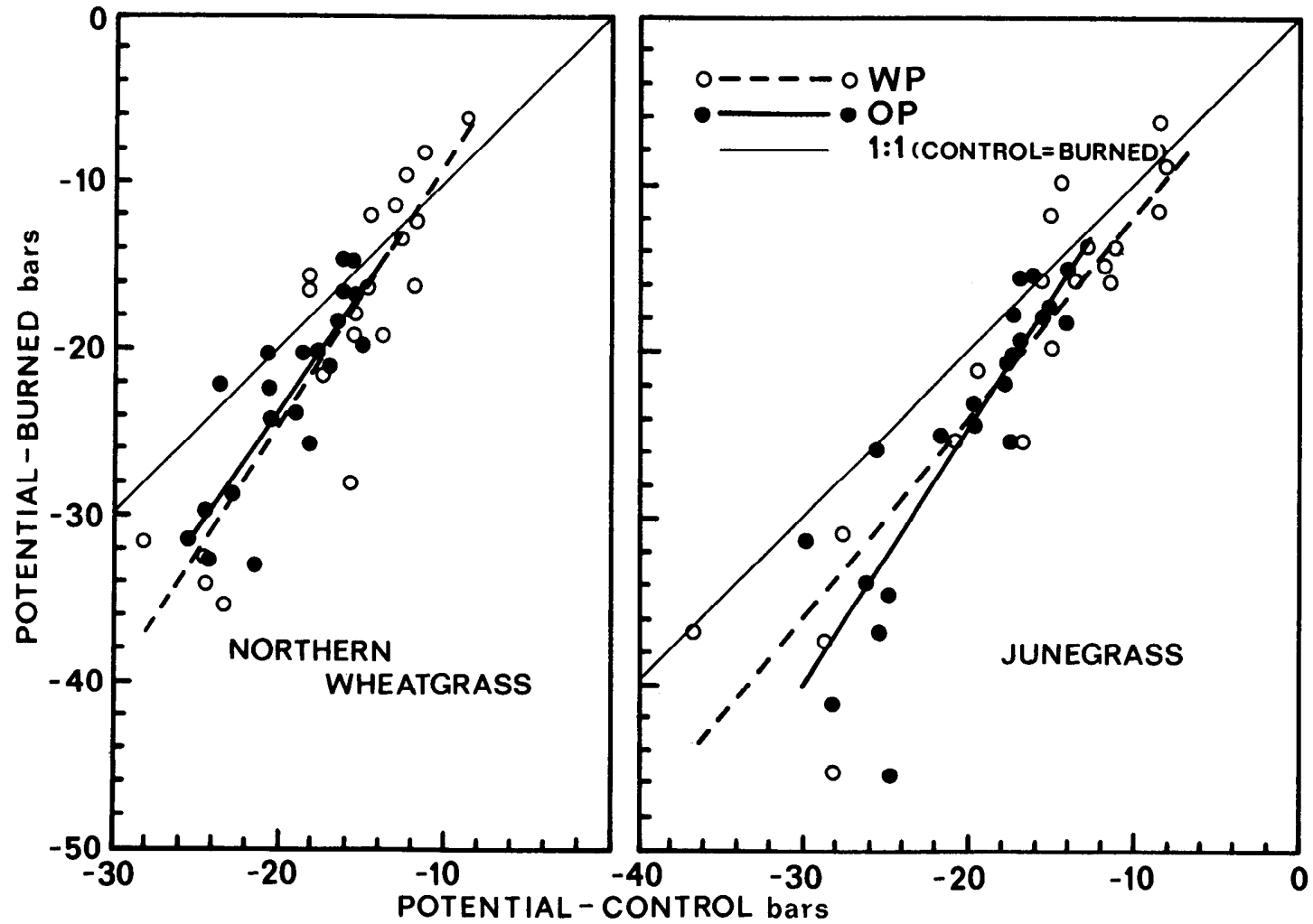

Fig. 2. Relationships between water potentials (WP) and osmotic potentials sions. Standard deviations for osmotic potentials of northern wheatgrass $(O P)$ of leaves of northern wheatgrass and junegrass from burned and unburned plots. Means of four replications were used in the linear regresaveraged 0.8 bars; for junegrass, 1.0 bars. All regressions were significant at the 0.01 level of probability. 
from deJong (1973), obtained on a nearby plot using a neutron probe, followed a similar pattern. Soil matric potentials on the control plot fell below -25 bars in late July; potentials in the burned plots were below -25 bars on every measurement date except one.

Soil matric potentials in the $0-15 \mathrm{~cm}$ layer were below plant water potentials measured during late July and August, indicating that lower portions of the soil profile must have been supplying water to the shoots. Water from deep in the profile is important for the survival of some shoot tissue during drought periods (Redmann 1976). Reduction in subsoil water would result in greater plant water stress, particularly during droughts, when deep moisture is of greater relative importance McMurphy and Anderson 1965).

Reasons for reduced soil moisture in the burned plots remain speculative. DeJong (1973) determined that soil moisture recharge in a Matador Station site burned in 1969 was reduced because of lack of standing dead vegetation which traps winter snow. The reduction in stored water in the profile to a depth of $150 \mathrm{~cm}$ was about $60 \mathrm{~mm}$ in May, which represented about $75 \%$ of the pecipitation coming as snow during the previous winter. Trlica and Schuster (1969) also reported less favorable spring soil moisture on fall-burned grassland because of reduced snow accumulation. Wight et al. (1975) measured greater snow depths and greater total snow cover on undisturbed native grassland compared to clipped plots. Other work has also documented the importance of snowtrapping in the Great Plains (Van Havern and Striffler 1968).

McMurphy and Anderson (1965) concluded that decreased infiltration rates, rather than reduced snow-trapping, explained lower soil moisture content on burned plots in eastern Kansas. Microclimatic changes resulting from fire also can influence plant and soil water relations (Daubenmire 1968).

\section{Effect of Fire on Primary Production}

Coupland (1974), studying a Matador Station site burned in August, 1969, found that peak green biomass the following season decreased by $28 \%$, despite the fact that pecipitation was $43 \%$ above the long-term average. Daubenmire (1968) and Wright (1974) cite several references which showed reductions in forage production after fire. Greater water stress in plants growing on burned sites can explain reductions in primary production which have been observed. A change in plant water potential from -20 to -25 bars results in a decrease in photosynthesis of approximately 60\% (Redmann 1973).

Fire in the semiarid grasslands appears to have a detrimental effect on plant productivity, as opposed to the beneficial effect reported in the more humid grasslands farther east (Vogl 1974). These detrimental effects can be traced to the influence of burning on snow hydrology, soil moisture, and ultimately, plant water status.

\section{Literature Cited}

Coupland, R.T. 1974. Producers: VI. Summary of studies of primary production by biomass and shoot observation methods. Matador Proj. Tech. Rep. 62. Univ. of Saskatchewan, Saskatoon. 84 p.

Coupland, R.T., and R.E. Johnson. 1965. Rooting characteristics of native grassland species in Saskatchewan. J. Ecol. 53:475-507.

Coupland, R.T., E.A. Ripley, and P.C. Robins. 1973. Description of site: I Floristic composition and canopy architecture of the vegetation cover. Matador Proj. Tech. Rep. 11. Univ. of Saskatchewan, Saskatoon. 54 p.

Daubenmire, R. 1968. Ecology of fire in grasslands. Adv. Ecol. Res. 5:209-266

de Jong, E. 1973. Soil physics: II. Soil water. Matador Proj. Tech. Rep. 22. Univ. of Saskatchewan, Saskatoon. 42 p.

de Jong, E., and J.B. Stewart. 1973. Description of site: III. Soil characterization. Matador Proj. Tech. Rep. 36. Univ. of Saskatchewan, Saskatoon. $30 \mathrm{p}$.

McMurphy, W.E., and K.L. Anderson. 1965. Burning Flint Hills range. J. Range Manage. 18:265-269.

Redmann, R.E.1973. Plant water relationships. Matador Proj. Tech. Rep. 29. Univ. of Saskatchewan, Saskatoon. $84 \mathrm{p}$.

Redmann, R.E. 1976. Plant water relationships in a mixed grassland. Oecologia (Berl.) 23:283-295.

Ripley, E.A. 1973. Description of site: II. Climatology of the Matador area. Matador Proj. Tech. Rep. 12. Univ. of Saskatchewan, Saskatoon. 112 p.

Rowe, J.S. 1969. Lightning fires in Saskatchewan grassland. Can. Field Nat. 83:317-327.

Steel, R.G.D., and J.H. Torrie. 1960. Principles and Procedures of Statistics. McGraw-Hill, New York.

Trlica, M.J., and J.L. Schuster. 1969. Effects of fire on grasses of the Texas high plains. J. Range Manage. 22:329-333.

Van Haveren, B.P., and W.D. Striffler. 1976. Snowmelt recharge on a shortgrass prairie site. Western Snow Conference Proceedings 44:56-62.

Vogl, R.J. 1974. Effects of fire on grassland. Pages 139-194 In T.T. Kozlowski and C.E. Ahlgren, eds. Fire and ecosystems. Academic Press, New York. Walter, H., and H. Leith. 1960. Klimadiagramm-Weltatlas. G. Fischer, Jena. Wight, J.R., E.L. Neff, and F.H. Siddoway. 1974. Snow management on eastern Montana rangeland. p 138-143 In: Snow management on the Great Plains. Great Plains Agricultural Council Publication /3. Univ. of Nebraska, Lincoln.

Wright, H.A. 1974. Effect of fire on southern mixed prairie grasses. J. Range Manage. 27:417-419.

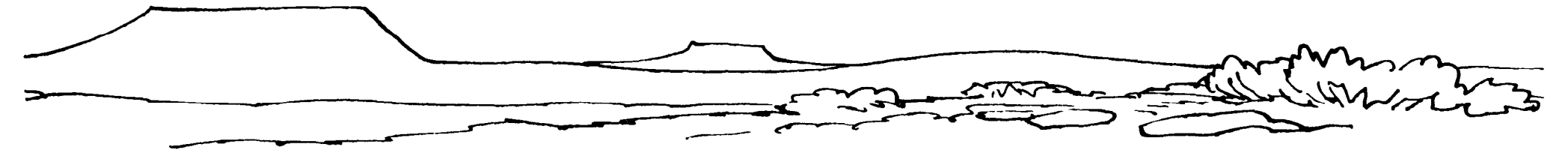

